\section{Evolution of Global Product DEVELOPMENT NETWORKS: AN EXPLORATORY STUDY}

Keywords: Global Product Development (GPD), GPD Networks, GPD Configurations, Chessboard, Retrospective Case Study.

\begin{abstract}
Global Product Development (GPD) networks have evolved to satisfy the unique requirements essential to the successful adoption of corporate outsourcing and offshoring during development processes. Having reviewed the relevant literature associated with GPD, this paper seeks to contribute to the understanding of organizational considerations taken by GPD networks during their transitional processes.
\end{abstract}

A retrospective case study analysis was conducted with 17 Italian companies classified into six GPD configurations (named the "Chess matrix"). Each classification was based on both developmental localization (local vs. global) and product development process fragmentation (development activities are either entirely performed within the same development lab, eventually with the contribution of support/adaptive units, or they are split among development units). Using this classification system, an evolutionary model was adopted to illustrate the dynamic paths companies follow when transitioning towards new GPD configurations.

With this framework and categorization process, it was deduced that three main variables drove each of the 17 companies: market needs, market extension and internal needs. These variables were determined based upon the GPD approach each company adopted in pursuit of a stable profitable configuration that was achieved by either deliberately remaining in a certain configuration or by employing an evolutionary GPD development configuration. In recognizing that there is not a singularly optimal stable configuration, it is essential to recognize and identify the individual drivers being pursued by each enterprise when implementing specific configurations. Further research will be devoted to more extensively elaborate the paths within a larger sample of companies to identify unrevealed paths and drivers that move companies in their product development globalization efforts.

\section{Managerial Relevance Statement}

This research seeks to contribute to the general understanding of GPD network processes and transitions. The possible configurations of GPD networks and the paths companies follow to achieve each configuration are delineated.

Through the use of a contingency approach presented in the paper, managers can identify the path(s) that reflect(s) their corporate objectives given their market and internal operating conditions.

For instance, a company pursuing a GPD strategy that is willing to balance the tradeoff between closeness to the final market, product standardization, and cost benefits of specialized development units can benefit from the establishment of a globalized network of specialized collaborative development units. In addition, if a company needs a specific product, support/adaptive units could be opened near the destination market. A support/adaptive unit can evolve into a full development lab once the corporate market position is established.

Companies willing to globalize their product development processes can learn the possible operational paths that can be followed to accomplish the strategic objectives they aim for.

\section{Introduction}

Global Product Development (GPD) has, over the past two decades, been defined based on political, economic, and social features. One of the most comprehensive - 
and cited - definitions is: " $a$ single, coordinated product development operation that includes distributed teams in more than one country utilizing a fully digital and connected, collaborative product development process" ([1]). The efforts of many analysts have yielded a huge amount of experiences and data on the offshoring of research and development departments, which aid in identifying the main motivations pushing modern companies to globalize their development processes (e.g., [2] [3]), understanding how the offshoring destinations depend on the country of origin (e.g., [4]), underlining the differences in GPD practices among countries (e.g., [5]; [6]), and investigating how research and development organizations can be structured (e.g., [7]).

The analysis (e.g., [7]; [4]; [1]) revealed that pure Research (R) is managed differently than mere product Development (D) and that these two functions do not always have to be kept together. A GPD approach is often based on a mix of internal and external players (e.g., external designers, co-design suppliers, and local providers), which composes a network of R\&D activities and teams [1] to be coordinated over time.

This paper aims to contribute to the analysis of GPD networks by assessing how this network should be adapted to a changing context. In contrast with other works conducted on this topic, this paper utilizes a "time perspective," which details how the GPD network has evolved/will evolve.

To achieve this, a retrospective empirical case study methodology was used [8] with an explorative objective. The empirical research is based on 17 industrial cases that are originally based in Italy and involve the development of products with both electric and mechanical technologies. The paper presents a literature review pertaining to GPD, with the aim of defining a reference taxonomy, in section 2. Sections 3 and 4 present the research questions and the research methodology, respectively. The results of the empirical research are represented in section 5 and discussed in section 6 , where a tentative model of the evolutionary paths adopted by the interviewed companies in GPD is discussed. Section 7 elaborates some final discussions and presents the paper's conclusions.

\section{Literature Review}

In this study, we investigated how companies change the design of their development unit network over time. We focus on development units; units devoted to long-term research activities are outside the scope of this study.

The literature has proposed taxonomies to classify development unit networks and the drivers of companies' choices in terms of unit network design.

\subsection{Taxonomies of development unit networks}

The existing literature on product development suggests that development unit network design pertains to the localization of units [9] and the organization of the development activities among the units [7], reflecting the type of development units involved in the network, e.g., by considering the nature of their tasks [10].

In [9], the modes of GPD are designed based on the ownership and localization of resources. Development units are then classified according to their roles and tasks in the development process. The classifications in the literature distinguish between development units that are devoted to performing only a small portion of the entire development process and units that perform most or all of the development process. According to [7], [12] and [13], R\&D units can be classified 
into four categories as follows: (i) Technology Scanning units, which are devoted only to monitoring the technology/market evolution; Supportive/Adaptive units, which provide technical support to other units or adapt products developed elsewhere to local market needs; (iii) Development Labs; and (iv) Research Labs, which are devoted to the management of development projects or research projects, respectively, e.g., aiming to explore new technologies. More recently, [14] divided the subsidiaries with limited tasks and low technology orientation into Local Adaptors and Extended Workbenches. These have high and low market orientation, respectively. Product Excellence Centers and Technology Excellence Centers are subsidiaries with higher autonomy in developing products and researching new technologies.

The investigated literature shows how development units are linked to each other to manage the challenging task of coordinating development activities in different locations [15]. To achieve project performance targets, tasks should be divided among units. This is particularly challenging in complex engineering systems [16]. Higher or lower autonomy might be given to development units based on the degree to which decision-making is centralized in another unit [17]. In [18] and [7], two major categories of global R\&D structures were identified:

Specialization-based, in which one unit is given full responsibility for developing a project; and (ii) Integration-based, in which different units contribute to the project. In [14], formal, informal and hybrid coordination mechanisms are distinguished, and [19] suggests crossnational teams. Global teams can be used to exploit globally dispersed competencies supported by electronic tools [20].

\subsection{Drivers leading the design of development unit networks}

Companies redesign their development unit networks due to various external and internal pressures. However, through the effective use of Information and Communication Technologies (ICTs), companies are able to satisfy these pressures while reducing offshore production/design costs [21] [1] [22] [23]. Table 1 and Table 2 summarize the main drivers for offshoring and onshoring. For instance, new development units can be opened offshore due to the need (i) to be closer to clients, e.g., to be able to better customize products for local markets [24]; (ii) to be closer to the production facilities to improve the coordination between development processes and manufacturing activities; or (iii) to access specific competencies or low-cost resources unavailable in the home country. However, centralization of resources in the home country guarantees efficiency. Advancements in ICTs facilitate the offshoring of R\&D units (e.g., [21]). However, in technology-intensive development processes, the cost of duplicating technology or training resources can prevent companies from moving R\&D units offshore.

There has been no attempt to link the taxonomies with the drivers, nor have company changes in terms of development unit network design been analyzed to date.

\section{Research Questions}

The redesign of a company development unit network is a complex and timeconsuming endeavor, and with globalization, this complication is compounded. Among researchers and practitioners in the field, it has been recognized that "Why globalize?" is best replaced by the concept of "How to optimize global operations?" [34]. However, there are currently very few tools and pieces of literature that can be used to support managers when defining 
this transformation path. For instance, [9] proposed a three-step approach to GPD deployment. They included outsourcing to external suppliers, but they did not provide details on the type and organization of the development unit network to choose at each step. Few other contributions found in the literature are able to provide an answer to such a topic. This work seeks to explore development unit network configuration changes and provide answers obtained through the evaluation of 17 companies to uncover any common paths and suggest possible strategies for creation of a global development unit network. Our research aims to answer the following research question: "How does development unit network configuration evolve over time?" We then plan to also contribute to the identification of the main reasons for time-based evolution ("Why do development unit networks evolve over time?"), if they exist.

\begin{tabular}{|l|l|l|}
\hline \multicolumn{1}{|l|}{ Drivers for offshoring } & References \\
\hline \multirow{4}{*}{ Market needs } & $\begin{array}{l}\text { Competitive pressures, product complexity, frequency } \\
\text { of innovations }\end{array}$ & $\begin{array}{l}{[1][2][4][7][11][21][24]} \\
{[25]}\end{array}$ \\
\cline { 2 - 3 } & Product diversification & {$[7][24][26]$} \\
\cline { 2 - 3 } & Importance of the local-abroad market & {$[2]$} \\
\cline { 2 - 3 } & $\begin{array}{l}\text { Other (e.g., cultural heterogeneity, access to } \\
\text { regulations and norms) }\end{array}$ & {$[2][4][24]$} \\
\hline \multirow{3}{*}{ Internal needs } & Access to distributed technologies and competencies & $\begin{array}{l}{[1][2][4][15][16][22][25]} \\
{[27][28][29][30]}\end{array}$ \\
\cline { 2 - 3 } & Integration of production and development activities & {$[1][2][4][22][24][28]$} \\
\cline { 2 - 3 } & Product standardization & {$[7][24][31]$} \\
\hline
\end{tabular}

Table 1. Drivers for localization decisions (offshoring)

\begin{tabular}{|l|l|l|}
\hline Drivers for onshoring & References \\
\hline Market needs & Importance of domestic market & {$[2]$} \\
\hline \multirow{4}{*}{ Internal needs } & $\begin{array}{l}\text { Avoid the redundancy and dispersion of product } \\
\text { development resources }\end{array}$ & {$[2][4][15][16][30][32][33]$} \\
\cline { 2 - 3 } & Integration of production and development activities & {$[1][25][31]$} \\
\cline { 2 - 3 } & Protect key competencies and knowledge & {$[24]$} \\
\cline { 2 - 3 } & Lack of technical equipment & {$[23][29]$} \\
\hline
\end{tabular}

Table 2. Drivers for localization decisions (onshoring)

When developing a product, companies utilize development teams to organize developmental activities and processes, e.g., by assigning resources to the activities. Thus, we define a "development unit network configuration" as the combination of the localization of the development units ([9] [35]), and the fragmentation of the development process.

○ Regarding the localization of resources, we focused on "offshoring", i.e., the relocation of activities to a foreign location where companies' activities are performed either under the company's own subsidiary or by a foreign contract vendor [11]. Development units can be located near the company or in the countries around the home country of the company (i.e., "Local") or far from the company; for example, if the company is European, the development units can be located in the Far East (i.e., "Global").

$\circ$ For the organization of the 
development teams, we focused on the fragmentation of the development process, i.e., the distribution of activities among the resources, and the type of development unit involved in the product development process. According to [36], a product development project encompasses different phases: (i) planning, (ii) concept development, (iii) systemlevel design, (iv) detailed design, (v) testing and refinement, and (vi) production ramp-up. Each phase can be performed by different resources, which can be located in different areas of the world or in the same building [20]. Therefore, the development activities can be (i) all performed within the same development unit or (ii) split among different units. In line with [7], we consider two types of development units:

"Development labs" and

"Support / Adaptive units".

We identified two axes, i.e., the localization of development units and the fragmentation of the product development process. Allowing for the composition of a matrix that outlines six different configurations (see Figure 1). This matrix was called "chess matrix", since the names of the configurations are taken from the names used in the game. The six configurations are as follows:

Castling: Companies adopting this configuration locate their product development units in only one country, and product development projects are completely performed within the walls of the same development lab.

Pawn: Companies belonging to this cell develop products in one or more development labs located in the same country, i.e., the home country of the company, but decide to let globally distributed support/adaptive units perform product customization activities.

Castle: Products are developed in more than one development lab localized in the same country, i.e., the home country of the company. A team composed of resources belonging to the different development labs performs the project. Therefore, there are no cultural differences among the resources, e.g., no differences in the language.

King: Companies in this cell are characterized by more than one development lab, whereas all development phases are managed within each single development lab, without coordination with the others.

King with Pawn: Companies in this cell are characterized by more than one development lab and some globally distributed support/adaptive units.

Queen: Companies in this cell are characterized by more than one development lab and projects split among development labs to be developed by globally distributed staff.

The set of drivers in Table 1 and Table 2 are used to investigate the reasons for the evolution over time of development units' configuration.

\section{Methodology}

A retrospective case study analysis was used as the investigation tool. Case studies are a powerful approach whenever there is a need to answer "how" and "why" questions [37]. Retrospective case research allowed for the study of phenomena in a natural setting, where meaningful insight could be gathered to develop a theoretical basis that is generated from understanding gained through the observation of actual practice [8] and reconstruction of the timeline of events and variables that changed over time. The benefits of the use 
of case studies include that it allows for the study of a phenomenon in its natural setting, thus allowing contextual elements to be captured; that it relies on the gathering of various sources of data, thus allowing triangulation; and that data collection and data analysis are guided by past theoretical developments to build new knowledge [37]. A structured approach was used to prevent and/or limit the drawbacks related to subjectivity. We performed multiple case studies, so we aimed to gain not the richness of detail that is reachable through a single in-depth case study but rather a fairly high and meaningful variety of cases. This fits our purpose of achieving a wide understanding of how different factors drive different organizations towards their global product development configurations.

In this study, the unit of analysis was the organization of product development activities in a company. The data were collected through an interview protocol that utilized semi-structured interviews, documentary analysis and company visits. This approach allowed for a detailed understanding of the complexity presented within each corporation while maintaining consistency across each case.

\subsection{Case Studies Selection}

Case studies were selected with a good sense of purpose [39]. Our purpose was to investigate different approaches to the organization of product development. Hence, companies that would provide different views of a similar topic were targeted. Companies were selected using both the literal replication technique to obtain convergent results, e.g., companies of similar sizes and with similar approaches to the market in terms of customization; and the theoretical replication technique to explore different practices in terms of product development organization [37]. Companies were selected to cover a range of corporation types and perspectives based on information gathered through secondary sources (websites and previous authors' experience) that the company had global development units and a willingness of interviewees to participate proactively throughout the research. An overview of the company details included in the study is shown in Table 3, along with the type of interviewee associated with each. In total, the organization of product development activities was investigated in 17 companies.

Companies selling products combining both mechanical and electronic technologies - applied in sectors such as automotive, machinery, and appliances were chosen. These industries encompass a wide range of different product types, ranging from batteries and electric control systems to motorcycles. This choice was utilized to standardize the corporation types and ensure repeatability across multiple cases, given that (i) the products are complex and consequently require complex development activities, (ii) the products are based on technologies used by customers spread across the world, and (iii) in this industry, companies are resorting to offshoring and outsourcing of development activities. In addition, the electromechanical sector represented in this study is one of the most relevant sectors in the Italian manufacturing industry, accounting for up to 15,000 companies and 300,000 employees [40].

\subsection{Selection of Interviewees}

Individuals with a view on the management of development projects and on the company development network were targeted for interviews. The interviewees comprised a mixture of $R \& D$ Directors, Project Engineers, Project Managers, Plant Managers and Sales Directors. They were selected due to their experience levels in the company (i.e., more than 10 years in the company and 6.5 years in the actual role). Moreover, aiming to have the point of view of the group 
rather than that of the subsidiary in Italy, the selected interviewees had a position in the company that allowed them to be strongly in touch with the headquarters, such that their perspective was that of the whole company.

For each company, a relationship with a senior manager was established to ensure that the corporation was committed to participating in the research. All interviews were tape-recorded and transcribed. A telephone follow-up with the respondents was conducted to assess the outcomes and - if needed - gather missing data. During the data collection process, we acquired archival data, such as websites, project descriptions and documentations that were used to facilitate a deeper understanding of each company. Additional institutional materials and documents were also used to reach a proper overall view of the company.

\begin{tabular}{|c|c|c|c|c|}
\hline Case & $\begin{array}{c}\text { Year of } \\
\text { foundation }\end{array}$ & $\begin{array}{l}\text { Number of } \\
\text { Employees }\end{array}$ & $\begin{array}{c}\text { Revenue (2011) } \\
\text { (K€) }\end{array}$ & Products \\
\hline Case 1 & 1977 & 250 & 30 & LED displays \\
\hline Case 2 & 1936 & 400 & 34 & Electric coils and solenoid valves \\
\hline Case 3 & 1945 & 700 & 60 & $\begin{array}{l}\text { Forks for forklift trucks, tools for } \\
\text { forklift trucks, aerial work } \\
\text { platforms }\end{array}$ \\
\hline Case 4 & 1886 & $>70000$ & 51500 & Electric control units for cars \\
\hline Case 5 & 1930 & 4000 & 750 & Axle shafts and gearboxes \\
\hline Case 6 & 1976 & 200 & 30 & $\begin{array}{l}\text { Payment machines and coin } \\
\text { identification machines, cash } \\
\text { machines for car wash }\end{array}$ \\
\hline Case 7 & 1888 & 15000 & 2700 & Batteries for cars \\
\hline Case 8 & 1903 & 243 & 70 & Motorcycles \\
\hline Case 9 & 1946 & 670 & 70 & Condensers \\
\hline Case 10 & 1982 & 220 & 20 & $\begin{array}{c}\text { Electronic modules and complete } \\
\text { systems }\end{array}$ \\
\hline Case 11 & 1913 & 280 & 70 & Forklift trucks for warehouses \\
\hline Case 12 & 1904 & 130 & 25 & $\begin{array}{c}\text { Home automation, residential } \\
\text { and industrial electrical devices } \\
\text { (e.g., switchers) }\end{array}$ \\
\hline Case 13 & 1885 & 336 & 50 & Lifting systems for heavy trucks \\
\hline Case 14 & 1974 & 230 & 35 & Industrial vacuum cleaners \\
\hline Case 15 & 1957 & 50000 & 10400 & Integrated circuits \\
\hline Case 16 & 1916 & 410 & 150 & Power transformers \\
\hline Case 17 & 1911 & 70000 & 18000 & Electric ovens \\
\hline
\end{tabular}

\subsection{Data Collection and Analysis}

The interview questionnaire (see Appendix 1) was split into headings that included company overview, localization of facility, markets and development units, product development with process description, localization of resources involved in the product development process and reasons for outsourcing/offshoring, development team organization, and plans for the future.
For the data collection, we used semistructured interviews. The semi-structured interviews can be considered a mix of both unstructured and structured elements [37], in which a list of sequential questions were used as a structured guide and open-ended additional questions could be introduced to stimulate the exploration of further arguments introduced by the interviewee(s) [38]. 
The data and content analysis was independently analyzed by three authors and then compared to achieve convergence. This allowed the authors to strengthen the reliability and completeness of the data analysis.

The data gathered from the structured portion of the interview was used to evaluate each configuration, independent evaluations were made from each author, and then the positioning was compared to reach an agreement. In depth discussions between the authors occurred to agree on companies' configurations, accurately define the evolutionary path each company had followed, and identify the motivational drivers moving companies to switch from configuration to configuration.

To understand the motivational drivers affecting company decisions, we relied on the unstructured interviews to provide detailed personal viewpoints. In addition, structured questions were utilized to identify why this evolutionary trend configuration had been followed. For example, in the case of Company 1, the $\mathrm{R} \& \mathrm{D}$ director declared that "we always managed our product development in this way, and we are not seeing the company changing it in the short run." This was strengthened by the data coming from the structured part of the interview, in which the interviewee stated that the reasons for avoiding product development globalization were to avoid resource decentralization and cost and time changes/complications. This labels Company 1 as "forever in a castling" configuration pattern.

\section{Case Studies}

Table 4 displays the actual configuration of the global product development network of the case studies. Four dimensions were considered to describe how companies arrange their global product development activities.
1. Fragmentation of product development process: explains whether the product development activities are all performed within a unique development unit or distributed;

2. Development labs: indicates whether the company owns more than one development lab and if these are globally located;

3. Supportive/adaptive units: states whether the company owns supportive/adaptive units; and

4. Localization of team: reports information on how the actors involved in the development project teams are located.

\section{Results}

In this section, the empirical evidence supporting the answers to the research question is presented.

\subsection{Taxonomy of development unit network configurations}

In all companies interviewed, development activities were performed either internally or in collaboration with external suppliers. Regarding the fragmentation of the product development process, companies distinguish between "development centers," i.e., development labs as defined by [7], and "technical interface centers," i.e., a type of supportive/adaptive unit, as defined by [7] and constituted by engineering offices devoted to performing the customization activities required for local customers. In particular, cases 2, 3, 10 and 12 utilized both development labs and supportive/adaptive units. It was found that the companies with supportive/adaptive units either developed products for the customer, forecasting their needs (Make to Order or Purchase to Order), or developed products based on customer requirements (Engineer to Order). 


\begin{tabular}{|c|c|c|c|c|}
\hline Case & Fragmentation of product development process & Development labs & $\begin{array}{c}\text { Supportive / } \\
\text { Adaptive units }\end{array}$ & $\begin{array}{c}\text { Localization of } \\
\text { product development team }\end{array}$ \\
\hline 1 & $\begin{array}{l}\text { Projects are all performed within the same } \\
\text { development lab and for the plant associated with } \\
\text { the development lab }\end{array}$ & One site in Italy & None & Co-located \\
\hline 2 & $\begin{array}{l}\text { Projects are all performed within the same } \\
\text { development lab and for the plants associated with } \\
\text { the development lab, whereas customization is } \\
\text { performed in one center }\end{array}$ & One site in Italy & $\begin{array}{l}\text { One in China, where the } \\
\text { activities from system } \\
\text { design until production } \\
\text { ramp up of products } \\
\text { customized for Chinese } \\
\text { markets are performed }\end{array}$ & Globally dispersed (Italy, China) \\
\hline 3 & $\begin{array}{l}\text { Projects are all performed within the same } \\
\text { development lab and for the plant associated with } \\
\text { the development lab, whereas customization is } \\
\text { performed in distributed centers }\end{array}$ & $\begin{array}{l}\text { More than one site, distributed } \\
\text { globally (Italy, Finland, } \\
\text { Germany) }\end{array}$ & $\begin{array}{l}\text { One unit in China and one } \\
\text { unit in USA. Products } \\
\text { already developed by the } \\
\text { other development labs are } \\
\text { adapted to local customers' } \\
\text { needs }\end{array}$ & $\begin{array}{l}\text { Globally dispersed (Italy, Finland, } \\
\text { Germany, China, USA) }\end{array}$ \\
\hline 4 & $\begin{array}{l}\text { Projects are all performed within the same } \\
\text { development lab }\end{array}$ & $\begin{array}{l}\text { More than one site located } \\
\text { globally (Germany, USA, } \\
\text { China, India) }\end{array}$ & No & $\begin{array}{l}\text { Co-located: the team is made up of } \\
\text { people working in the same development } \\
\text { lab. If needed, they resort to } \\
\text { competencies available in other } \\
\text { development labs or in the plants }\end{array}$ \\
\hline 5 & Projects are split among development labs & $\begin{array}{c}\text { More than one site located } \\
\text { globally (Italy, India, Argentina) }\end{array}$ & No & $\begin{array}{c}\text { Globally dispersed: the team is made up } \\
\text { of people working in different } \\
\text { development labs }\end{array}$ \\
\hline 6 & $\begin{array}{l}\text { Projects are all performed within the same } \\
\text { development lab }\end{array}$ & One site in Italy & No & Co-located \\
\hline 7 & $\begin{array}{l}\text { Projects are all performed within the same } \\
\text { development lab }\end{array}$ & $\begin{array}{l}\text { More than one site located } \\
\text { globally (Italy, Poland, Spain, } \\
\text { Germany) }\end{array}$ & No & $\begin{array}{l}\text { Co-located: the team is made up of } \\
\text { people working in the same development } \\
\text { lab and located near the production } \\
\text { facilities }\end{array}$ \\
\hline 8 & $\begin{array}{l}\text { Projects are all performed within the same } \\
\text { development lab }\end{array}$ & One site in Italy & No & Co-located \\
\hline 9 & $\begin{array}{l}\text { Projects are all performed within the same } \\
\text { development lab }\end{array}$ & One site in Italy & No & Co-located \\
\hline
\end{tabular}




\begin{tabular}{|c|c|c|c|c|}
\hline 10 & $\begin{array}{l}\text { Projects are all performed within the same } \\
\text { development lab, whereas customization is } \\
\text { performed in support/adaptive unit }\end{array}$ & $\begin{array}{l}\text { More than one site (Italy, } \\
\text { Germany) }\end{array}$ & One in China & $\begin{array}{c}\text { Globally dispersed (Italy, Germany, } \\
\text { China) }\end{array}$ \\
\hline 11 & $\begin{array}{l}\text { Projects are all performed within the same } \\
\text { development lab }\end{array}$ & $\begin{array}{c}\text { More than one global site (Italy, } \\
\text { Netherlands, Ireland, Japan, } \\
\text { USA) }\end{array}$ & No & Co-located in the same development lab \\
\hline 12 & $\begin{array}{c}\text { Projects are all performed within the same } \\
\text { development lab, whereas customization is } \\
\text { performed in support/adaptive unit }\end{array}$ & One site in Italy & One unit in UK & Globally dispersed (Italy, UK) \\
\hline 13 & $\begin{array}{l}\text { Projects are all performed within the same } \\
\text { development lab }\end{array}$ & One site in Italy & No & Co-located \\
\hline 14 & $\begin{array}{l}\text { Projects are all performed within the same } \\
\text { development lab }\end{array}$ & One site in Italy & No & Co-located \\
\hline 15 & Projects are split among development labs & $\begin{array}{l}\text { More than one global site (Italy, } \\
\text { France, India, China, Turkey) }\end{array}$ & No & $\begin{array}{c}\text { Globally dispersed (Italy, France, India, } \\
\text { China, Turkey) }\end{array}$ \\
\hline 16 & Projects are split among development labs & $\begin{array}{l}\text { More than one site in the same } \\
\text { country }\end{array}$ & No & Dispersed in the same country \\
\hline 17 & Projects are split among development labs & $\begin{array}{l}\text { More than one global site (Italy, } \\
\text { USA, India, Sweden) }\end{array}$ & No & Globally dispersed \\
\hline
\end{tabular}

Table 4. Actual configuration of the global product development network 
In all cases, the concept development for the products to be customized is performed by one development lab, with preference given to the facility in the home country of the company. Supportive/adaptive units then perform, supported by development labs, all phases starting with detailed design or, as in cases 2 and 12, system design. Supportive/adaptive units were located where the companies felt that the market needed specific product variants and adjustments ("for clients, having a direct local interface makes things easier. For instance, a supportive/adaptive unit is fundamental to operate in China: asking a Chinese client to call Italy to discuss technical issues related to his/her product would be impossible, both for time zone and cultural distance," states the R\&D Manager of case 10), or to be closer to production facilities. Generally, strong information exchange exists between the supportive/adaptive unit and the development lab.

When companies had one or more development labs, either they performed the development phase entirely within the walls of a development lab (cases 1, 4, 7, $8,9,11,13$ and 14) or the development activities were split between the development labs and performed jointly by resources belonging to the different development labs (cases 5, 15, 16 and 17). In the first situation, the development labs did not collaborate. In the latter, resources belonging to different development labs worked together on the same project, collaborating via face-to-face meetings or ICT-based tools. Development labs were found to be able to collaborate on all phases of the project, as in cases 15, 16 and 17 , or in the phases starting with system design, as in case 5 where concept design is performed by the development lab in the home country of the company in which the head of the Sales Department is located.

Global teams existed when development labs were located in different countries (as in cases 5, 15 and 17), and the resources of the different development labs collaborated. Despite the availability of ICT-based tools able to support virtual and remote collaboration, global teams still mainly worked via face-to-face interaction. For example, in case 17, a person from each division must physically participate in the face-to-face meetings (one or more per week) that are held in one of the divisions. Although the number of face-toface meetings in case 15 is not as frequent as that in case 17, they organize many face-to-face meetings both to report and solve difficult issues and to reduce the problem of time zone differences.

Figure 1 shows how the analyzed case studies are mapped using the chess matrix. The results suggest that firms either deliberately remain in a certain configuration or change their development unit configuration over time. For instance, cases 2 and 12 claim that their supportive/adaptive units will be upgraded to development labs. In the following sections, first the paths used by companies to reach the different configurations are described, and then the drivers for each movement are discussed.

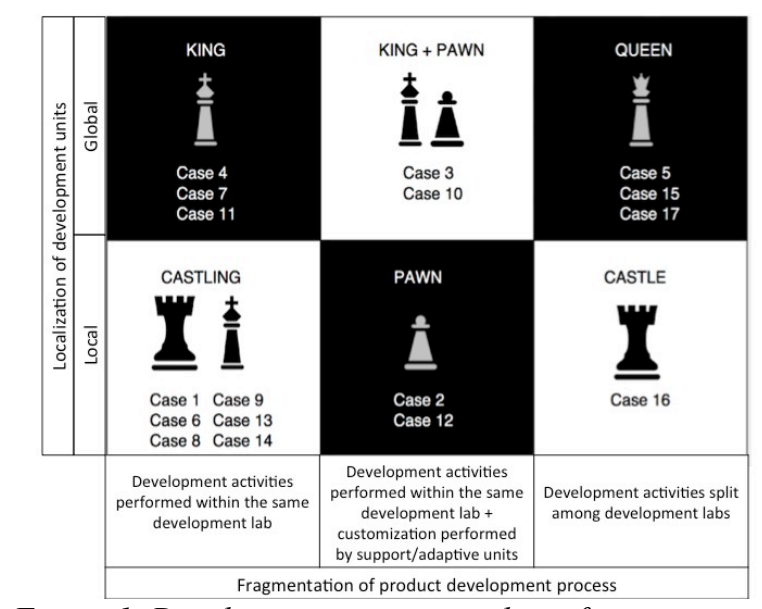

Figure 1. Development unit network configuration chessboard

\subsection{Development unit configuration paths}

Figure 2 depicts the movements in the development unit configuration chessboard. There were three stable 
configurations, from which companies in the long term might not plan to move away: (i) Castling, (ii) Castle and (iii) Queen. There are then some transitional configurations, from which companies plan to move away. Castling is both a stable configuration - for all those companies that in the long run do not plan to change - and the initial configuration for all of the companies. Because we do not observe any case in which companies go back to the castling position or express that they will do so, we can safely assume that this is a stable position.

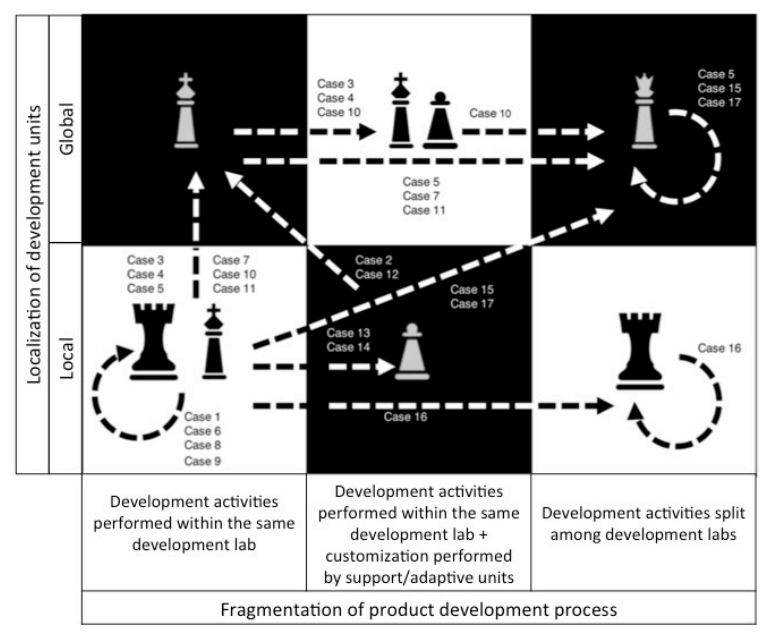

Figure 2. Chess Configuration Paths

Among these, there are three main possibilities when companies decide to move away from their actual configurations:

a. Opening new supportive/adaptive units/development labs. With regard to opening new supportive/adaptive units, this is the case of Pawn and King with Pawn, as in cases 3, 4, 13, and 14 . With regard to opening new development labs, this is the case of King. This can be accomplished by (i) opening new development labs from scratch (as, for instance, in cases 5 and 7), (ii) acquiring other companies (as in cases $3,4,7,10,11$ ), or (iii) upgrading already existing supportive/adaptive units to a development lab (as in cases 2 and 12).

b. Making existing development labs collaborate. This is meant to reach the
Castle configuration directly from Castling, as in case 16 and to reach Queen directly from King, as in cases 5,7 and 11 .

c. A combination of the two previous options. This is meant to reach Queen directly from Castling, as in cases 15 and 17 , or to move from King with Pawn to Queen, as in case 10. In this case, a new development lab has in fact been opened to replace the supportive/adaptive unit.

The reasons for staying in a configuration or moving are summarized in Table 5 and discussed in the following sections. In Table 5, for each configuration (displayed in columns), either stable or transitional, the driver (displayed in rows) for which each company decides to move or stay in a specific configuration is detailed.

\subsubsection{Staying in the same configuration}

The reasons behind the choice not to move from a stable configuration, i.e., Castling, Castle and Queen, are grounded in the market or in the internal needs of the companies and are different depending on the configuration. In particular, in the following, the drivers observed in the sample for staying in each cell are listed.

Forever Castling. Some companies chose to stick to the Castling configuration for the following reasons:

- Market needs, because the internal market is extremely relevant and constitutes a considerable percentage of the overall company market share (case 12).

- Internal needs, mainly addressed to avoid scattering of internal resources (cases 1, 6, 8, and 9), to reduce development costs, such as logistic and coordination costs (1), to avoid resource redundancy $(6,9)$, to maintain integrated development and production (13) and to elude risky markets (6). 


\begin{tabular}{|c|c|c|c|c|c|c|c|}
\hline \multirow{2}{*}{\multicolumn{2}{|c|}{ Driver for moving/staying }} & \multicolumn{3}{|c|}{ Stable configurations } & \multicolumn{3}{|c|}{ Transitional configurations } \\
\hline & & Castling & Castle & Queen & King & King \& Pawn & Pawn \\
\hline \multirow{7}{*}{ 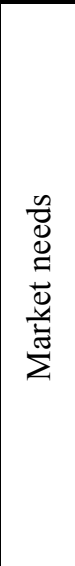 } & Relevance of domestic market & 1 (company 12) & & & & & \\
\hline & Relevance of local - abroad market & & & & $\begin{array}{l}5 \text { (Companies } \\
2,3,4,10,12)\end{array}$ & & $\begin{array}{l}2 \text { (Companies } \\
2,12)\end{array}$ \\
\hline & Dispersed markets & & 1 (Company 16) & & & & \\
\hline & Market proximity - time to reach the market & & & $\begin{array}{c}2 \text { (Companies } \\
10,15)\end{array}$ & $\begin{array}{c}3 \text { (Companies } \\
3,4,10)\end{array}$ & 1 (Company 3) & $\begin{array}{c}2 \text { (Companies } \\
2,13)\end{array}$ \\
\hline & Need of customization & & & & & $\begin{array}{c}2 \text { (Company } 3 \text {, } \\
\text { Company } 4)\end{array}$ & \\
\hline & Product diversification & & & & $\begin{array}{c}3 \text { (Companies } \\
4,7,11)\end{array}$ & & \\
\hline & Product complexity & & & & $\begin{array}{l}2 \text { (Companies } \\
3,4)\end{array}$ & & \\
\hline$\pm \underset{0}{\stackrel{0}{x}}$ & Access to know-how/technologies/competencies & & & $\begin{array}{c}4 \text { (Companies } 5 \\
11,15,17)\end{array}$ & $\begin{array}{c}5(\text { Companies } \\
3,4,7,10,11) \\
\end{array}$ & $\begin{array}{c}2 \text { (Companies } \\
3,4) \\
\end{array}$ & \\
\hline \multirow{8}{*}{ 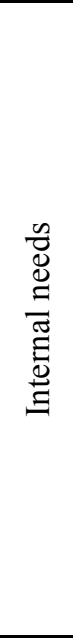 } & Avoid dispersion of resources & $\begin{array}{c}4 \text { (Companies } 1,6 \text {, } \\
8,9)\end{array}$ & 1 (Company 16) & & & & $\begin{array}{c}3 \text { (Companies } \\
2,13,14)\end{array}$ \\
\hline & Avoid redundancy in resources & $2($ Companies 6,9$)$ & 1 (Company 16) & $\begin{array}{c}\text { (Companies } 5, \\
17)\end{array}$ & $\begin{array}{c}2 \text { (Companies } \\
3,7)\end{array}$ & & \\
\hline & $\begin{array}{l}\text { Integrate product development and production } \\
\text { and/or other departments }\end{array}$ & 1 (Company 13) & & $\begin{array}{c}3 \text { (Companies } 5 \text {, } \\
10,15)\end{array}$ & $\begin{array}{c}3 \text { (Companies } \\
7,10,11)\end{array}$ & $\begin{array}{c}1 \text { (Company } \\
10)\end{array}$ & \\
\hline & $\begin{array}{c}\text { Cost reduction } \\
\text { (development/logistics/coordination...) }\end{array}$ & 1 (Company 1$)$ & & $\begin{array}{c}3 \text { (Companies } 5 \\
15,17)\end{array}$ & 1 (Company 10) & $\begin{array}{c}1 \text { (Company } \\
10)\end{array}$ & \\
\hline & $\begin{array}{l}\text { Protect key competence and know-how (e.g., } \\
\text { patents) }\end{array}$ & 1 (Company 6) & & & & & $\begin{array}{c}1 \text { (Company } \\
14)\end{array}$ \\
\hline & Cultural reasons & & & & & $\begin{array}{c}2 \text { (Companies } \\
3,10)\end{array}$ & \\
\hline & Elude risky markets & 1 (Company 6) & & & & & \\
\hline & Product standardization & & & $\begin{array}{c}5 \text { (Companies } 5 \\
7,11,15,17) \\
\end{array}$ & & 1 (Company 4) & \\
\hline
\end{tabular}

Table 5. Drivers for each configuration. The number in each cell relates to the number of companies in each configuration (column) that claim that driver (row) to be relevant for the decision. 
Case 6 emphasizes how "opening development centers abroad is extremely expensive; moreover, there is high uncertainty whether that market is significant." Case 9 promotes the use of some itinerant development teams delegated to visit its three Italian development sites with few logistic costs (all sites are in close proximity) with the purpose of accessing their unique technologies and operational competencies.

Because the development teams move across plants with low expenses, case 9 avoids "duplication of resources with this efficient method able to guarantee a development cost definitely affordable for a company with such a dimension. However, to have development centers dislocated in each plant would increase effectiveness, such as time to market. However, this would increase cost due to the duplication of resources." Moreover, this configuration is chosen to facilitate communication between the project team, co-located in one site. All cases highlight the importance of having a co-located team with the aim of protecting key competencies and knowledge.

Forever Castle. The Castle configuration is a long-term position that is maintained for the following reasons:

- Market needs, when the destination market of a company is highly mixed and not concentrated in particular areas (16).

- Internal needs, mainly to avoid scattered development resources (16).

Forever Queen. It seems that companies that are able to reach the Queen configuration aim to preserve this position, which becomes, for them, a regime modus operandi. This is because of the following:

- Market needs, to continue satisfying the customers' needs of closeness to their production sites (15).

- Market extension, to maintain the access to dispersed competencies and technologies $(5,15$, and 17) obtained by the acquisition of external organizations (15 and 17).

- Internal needs, to maintain synergies to avoid resource redundancy (17), maintain integrated product development and production $(5,15)$, increase product diversification $(5,15$, 17), maintain the cost advantage $(5,15$, 17), or guarantee standardization (5, 15, 17). Although Company 15 owned many design centers around the world and some development units through which it introduced new products into the marketplace, the main strategy is to maintain the core design competencies in the Western countries and continue development with global teams. "When we bring a product with a high technological content to be produced in the emerging countries, we lose the technology advantage. If we also bring the whole design in there, we will lose our main competitive advantage. That is why it is not desirable to de-locate the full development in developing countries (such as China and India)" (case 15). In case 5, collaboration between people from different development labs had a tremendous impact on the innovativeness of the products. Case 5 leverages global teams to share the competencies of different development labs: "The idea behind global teams is that people in working in a development lab in a certain area have stronger knowledge in the competencies required by the local market. Therefore, global teams allow [us] to have in the team the best competence available in the company, regardless of where it is located," stated the R\&D Manager of company 5.

\subsubsection{Moving to a new position}

There are configurations that can be the actual, past or future configuration of a company. In fact, companies reaching King, King with Pawn and Pawn 
frequently decide to move to another configuration. Apart from King with Pawn, all configurations can be reached in one movement starting from Castling. However, many companies have chosen a step-by-step approach, moving from one configuration to another over time. This is due to the cost involved in each step and the fact that companies react to external and internal drivers. In the following, the drivers for moving to a certain configuration are discussed.

Becoming Pawn. Companies can move from the Castling configuration to Pawn because of the following:

- Market needs, when a company is required to have sites closer to its customer production facilities and to guarantee proximity to strategic markets $(2,13)$, to exert more control on tactical markets (2) and to provide specific products for the local market (13). This is obtained by means of acquisitions (12). For example, the initial phase of concept development was always performed in Italy for company 2, whereas the rest of the development is done in Italy for the global market and in China for the local market, through the supportive/adaptive unit. This is because "the customers required part of development and production in loco" (2). Similarly, case 12 starts every development project in Italy and customizes the products for the English market in the UK, where it owns a supportive/adaptive unit to concretize its strong presence in the local market. Company 12 entered the foreign market with a supportive/adaptive unit but kept its development resources located in Italy due to the local market relevance.

- Internal needs, when, although a company is pushed to have sites close to foreign customers, the investment of an entire development lab is not sustainable, and the choice to dislocate with a supportive/adaptive unit is given not to scatter development resources (2, 13, and 14): "customization in a foreign market does not justify the dispersion of resources. To think about dislocated product development is still premature" (13). Although case 14 increased its size and number of sites over the years, it was decided to maintain its development sites in Italy to protect and control its know-how and patents and to only delocalize with the supportive/adaptive unit.

Becoming Castle. When a company with development sites in only one country (in our cases, Italy) decides to start collaborative development projects across intra-site teams, it moves from castling to the castle configuration. This is because of the following:

- Internal needs, such as entering different competencies within the company's resources. In case 16, different development labs in Italy collaborate to develop new projects in $30-40 \%$ of cases. This is because of non-standard projects that are run and require the competencies of different actors in the company. In contrast, if the products are standard, intra-site collaboration is not required.

Becoming King. The King configuration can be reached from the Castling position. In particular, this occurs because of a set of reasons:

- Market needs, such as competitive pressure, product complexity, ability to quickly answer market demand (3 and 4 ), customer need for the site to be close to their production facilities (10), relevance of the overseas market (10) or need for the segmentation of products $(7,11$ and 4$)$.

- Market extension, such as the need to access different sectors where the company does not have know-how (10) and distributed technologies and competencies (3, 7, 11 and 4), or foreign company acquisitions $(3,7,11$, 4 and 10). 
- Internal needs, such as the need to maintain design near production facilities (7, 10 and 11), reduce development costs (10), or reach unique competencies owned by the single development unit (7 and 3). "It is fundamental to have design near the production site," stated the Product Development Team Manager of case 7. Sometimes, companies are motivated to move from Pawn to King for the following reasons:

- Market needs, when a foreign market is sufficiently prevalent to require that a supportive/adaptive unit become a full development lab $(2,12)$. This is the case of the Chinese technical center of case 2 , which is now moving toward this direction: "We have a technical department in China where two engineers operate to develop new products for the local market, from the second stage of the product development (after the concept is defined)." In addition, "we operate in UK through a technical center where products are customized and roughly developed through an embryonic development process" (12).

Becoming King with Pawn. Companies move from the King configuration into the King with Pawn configuration because of the following:

- Market needs, when supportive/adaptive units are located where the company feels that the market needs specific product variants and adjustment (cases 4 and 10). Case 4, while claiming the need for standardization, also looks for customization: "there is a soul looking for standardization and a soul looking at customization based on the kind of customer you have. Usually, in ordinary development, we try to standardize first and customize afterwards," said the R\&D Manager.

In case 3, the supportive/adaptive unit is specifically used to be closer to the customer, especially when he/she needs to be involved starting with the early phases of development, to make dedicated products.

- Market extension, to access dispersed technologies and competencies ( 3 and 4) or acquire foreign companies $(3,4$ and 10).

- Internal needs, such as standardization needs for case 4 . Cultural heterogeneity can prevent companies from opening development labs but allow them to pursue supportive/adaptive units (3 and 10). Company 10 was pushed by cultural reasons to open supportive / adaptive units in China due to communication difficulties between Italian engineers and Chinese customers. In addition, there could be cost reasons and a willingness to integrate production and development (case 10).

Becoming Queen. This configuration is achieved because of the following reasons:

- Market needs, customers required the company to have development sites near their markets (cases 10 and 15).

- Market extension, to access dispersed competencies and technologies to develop additional products to address new markets (5, 11, and 15) through external company acquisition strategies (11, 15, and 17). For example, case 15 acquired companies in which particular competencies and patents were retained. Further, "the main reason was to enter dispersed competencies and technologies. The American (or European) designers can bring their competencies for realizing a better product. Additionally, the American designers could dispose with competencies on specific technologies or processes not available in Europe; therefore, there is an exchange of competencies. [...] There is a continuous exchange of competencies" (R\&D Manager, case 17).

- Internal needs, such as product standardization to reduce project complexity (cases 5, 7, 11, 15, and 17). 
For example, company 7 was moving from a King to a Queen configuration because people from different centers are increasingly involved in collaborative development projects: "Since we are trying to develop homogeneous products, there will be more and more development centers that will develop similar products and that will collaborate for their development. [...] The trend is that each development center will not take care anymore of the development for a single customer, but it will be in charge of the development of a specific product that will be sold globally. This will reduce complexity. There is actually a team in charge of the whole development; [the person] is in charge of production is involved from the beginning in order to be aware about the complexity of the project and in order to provide feedback regarding constraints from the production plan. The team is global from the first stages of the development" (R\&D Manager case 7). Another reason could be to create synergies to avoid resource redundancy: "The reason why we decided to let Italian and American sites co-develop ovens, it is because of pure synergy" (R\&D Manager case 17). Additionally, companies can move to the Queen configuration because of the need to integrate development with other company's functions $(5,10$, and 15): "Every site is dedicated to different products. We are working to make the integration within functions higher and higher. We are now in the process of integrating the product design and purchasing departments. To reach this objective, we are moving toward a certain degree of interchangeability of our technologies. [...] We are also moving toward a centralized management of our functions, which is not in place at the moment. [...] A roadmap is now in place to integrate the different realities of our company's network. [...]" (R\&D Manager case 10). Finally, a reason could be the reduction of development costs; for example, case 15 created a series of design centers in China, India and Turkey because of the low labor cost in those areas; the engineers are in charge of the general design as soon as other sites have generated the main concept of the product.

\section{Discussion and Conclusions}

The results suggest that firms either deliberately remain in a certain configuration or change their development unit configuration over time. The stable configurations, i.e., those from which companies seem unwilling to move, are characterized by the presence of only development labs. Companies choosing to keep their development labs within the borders of their home country mostly chose to have development labs that specialize in the development of specific product lines. Therefore, development labs work independently in most cases. Conversely, when development labs are located globally, companies seem to strive to reach a configuration in which each development lab is specialized in specific activities, and the development process is therefore performed collaboratively.

Companies change their configurations following similar patterns. Interestingly, the final position of all paths is one of the stable configurations. Despite this, there is no optimal stable configuration that all companies strive to reach, and there is no best configuration to be taken a priori. Figure 3 summarizes the results of the analysis of the paths and the drivers. All companies start from the Castling configuration. The decision to offshore is mainly driven by the desire to serve new markets and offer customized products (see Table 5 for details). Interestingly, it was found that companies that decide to offshore normally do not decide to re- 
shore, at least in the time frame observed. The decision to keep development labs within the borders of the home country is driven instead by the search for efficiency, so the restraint of the high costs of resource duplication (cases 6,9 and 16) and coordination (cases 1, 2, 6, 8, 9, 13, 14, and 16) are connected to the globalization of product development resources. The decision to offshore can result in companies opening either supportive/adaptive units or development labs abroad that are working independently or development labs working collaboratively.
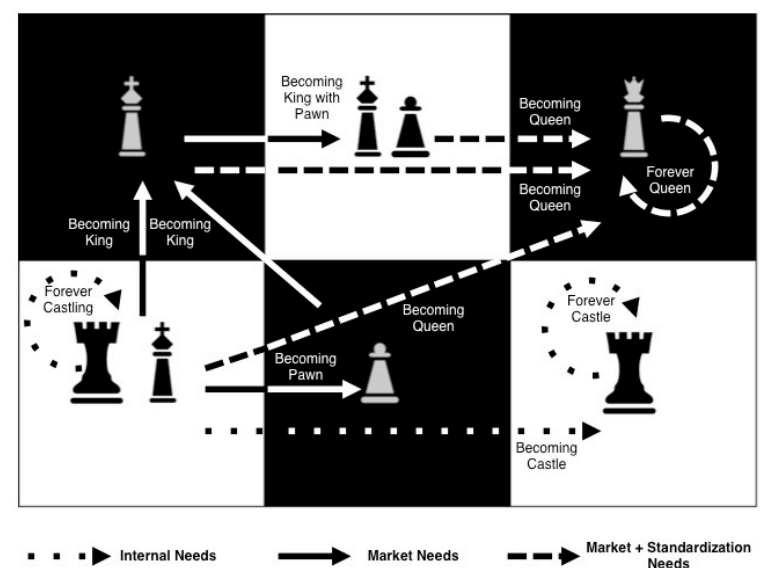

Market + Standardization

Figure 3. Drivers for Chess Configuration Paths

The pawn configuration is one of the first steps on the paths moving companies to King and then on to Queen. It can be seen as the simplest first attempt by companies to move towards globalization without incurring the high costs connected with the duplication of resources (as in cases 1, 12, and 13).

All companies that moved to Queen reported that one of the drivers for moving or staying in this configuration was product standardization. This is because, as cases $5,7,11,15$, and 17 suggest, when the complexity associated with a global network of development units increases, the costs associated with the complexity of coordination grow as well. Moving to the Queen configuration allows companies to balance the need to be close to markets with the cost benefits of development lab specialization and high standardization.

The results of this work suggest interesting insights for decision-makers in research, development and engineering management. With this work, engineering managers can have a list of possible codified paths to follow when globalizing their product development. We identified a set of possible development unit network configurations, along with the paths to follow to move from one configuration to another. Put differently, given the strategic objective of a company to globalize its product development process, we propose the possible operational paths to follow to reach this objective, given the drivers companies are experiencing. As stated, we do not have elements -as it was not the purpose of our retrospective research- to state which configuration is the best in general and which is the best for one specific company. However, we describe several paths to be followed to reach companies' strategic objectives depending on market and internal drivers. For instance, consider a company in the castling position that aims to achieve a global collaborative product development network (Queen). If it is moved by standardization needs, it would more likely directly open new development labs worldwide and make them collaborate, without going through a King configuration that does not easily support standardization efforts (see Figure 3).

Apart from these, the present work has some other limitations commonly associated with exploratory research because it generates qualitative information that can be subject to bias, and the modest number of investigated cases might not perfectly reflect the totality of the population. To moderate the effect of bias, we applied the case study methodology proposed by [37]. Moreover, the impact on drivers of variables such as product complexity, product architecture and modularization has not been 
considered to keep the number of variables manageable and meaningful for the sample size. Additionally, we could not determine a clear impact of companies' characteristics, such as size, years of activity, and market position, on the considered drivers. We have limited our research -for the mentioned reasons- to one reference sector, which has its peculiarities. We can expect that the type of sector and industry has some impacts as well on the paths towards the different configurations, but we do not have assured data to support this thesis (or its opposite). Additionally, research centers, i.e., ones devoted to long-term research, were not considered in our investigation.

Future research will be devoted to testing the configurations and the configuration paths with a larger sample of companies and industries. This would allow other possible configurations and drivers to be identified. In future studies, the performance of each configuration will be studied as well to, for instance, investigate why King is not a stable position. Finally, the effects of contingent variables, e.g., industry, culture, and level of competition on the domestic and foreign market, on the choices of the configuration path will be studied as well.

\section{References}

[1] S. D. Eppinger and A. R. Chitkara, "The New Practice of Global Product Development," MIT Sloan Manag. Rev., vol. 47, no. 4, pp. $22-$ 30, 2006.

[2] N. Kumar, "Determinants of location of overseas R\&D activity of multinational enterprises: the case of US and Japanese corporations," Res. Policy, vol. 30, no. 1, pp. 159-174, 2001.

[3] S. V. R. Galina and G. A. Plonski, "Global product development in the telecommunication industry: an analysis of the Brazilian subsidiaries involvement," in
Proceedings of the 9th International Product Development Management Conference, European Institute for Advanced Studies in ManagementEIASM, 2002.

[4] M. Von Zedtwitz and O. Gassmann, "Market versus technology drive in R\&D internationalization: four different patterns of managing research and development," Res. Policy, vol. 31, no. 4, pp. 569-588, 2002.

[5] A. C. Perrino and J. W. Tipping, "Global management of technology," Res. Technol. Manag., vol. 32, no. 3, pp. 12-19, 1989.

[6] J. Cantwell and R. Harding, "The internationalisation of German companies' R\&D," Natl. Inst. Econ. Rev., vol. 163, no. 1, pp. 99-115, 1998.

[7] V. Chiesa, "Global R\&D project management and organization: a taxonomy," J. Prod. Innov. Manag., vol. 17, no. 5, pp. 341-359, 2000.

[8] J. Meredith, "Building operations management theory through case and field research," J. Oper.

Manag., vol. 16, no. 4, pp. 441-454, 1998.

[9] S. D. Eppinger and A. R. Chitkara, "The Practice of Global Product Development," MIT Sloan Manag. Rev., no. 50437, p. 14, 2009.

[10] W. Kuemmerle, "Building effective R\&D capabilities abroad," Harv.

Bus. Rev., vol. 75, pp. 61-72, 1997.

[11] F. J. Contractor, V. Kumar, S. K. Kundu, and T. Pedersen, "Reconceptualizing the firm in a world of outsourcing and offshoring: The organizational and geographical relocation of highvalue company functions," $J$. Manag. Stud., vol. 47, no. 8, pp. 1417-1433, 2010.

[12] G. Hewitt, "Research and development performed abroad by US manufacturing multinationals," Kyklos, vol. 33, no. 2, pp. 308-327, 
1980.

[13] R. D. Pearce and S. Singh, The internationalisation of research and development by multinational enterprises: a firm-level analysis of determinants. University of Reading, 1990.

[14] M. Zeschky, M. Daiber, B. Widenmayer, and O. Gassmann, "Coordination in global R\&D organizations: an examination of the role of subsidiary mandate and modular product architectures in dispersed R\&D organizations," Technovation, vol. 34, no. 10, pp. 594-604, 2014.

[15] E. G. Anderson, A. Davis-Blake, S. Erzurumlu, N. Joglekar, and G. Parker, "The effects of outsourcing, offshoring, and distributed product development organization on coordinating the NPD process," Handb. NEW Prod. Dev. Manag. C. Loch, S. Kavadias, eds., Elsevier, 2007.

[16] A. Tripathy and S. D. Eppinger, "Organizing global product development for complex engineered systems," Eng. Manag. IEEE Trans., vol. 58, no. 3, pp. 510-529, 2011.

[17] S. Young and A. T. Tavares, "Centralization and autonomy: back to the future," Int. Bus. Rev., vol. 13, no. 2, pp. 215-237, 2004.

[18] V. Chiesa, "Managing the internationalization of $\mathrm{R} \& \mathrm{D}$ activities," Eng. Manag. IEEE Trans., vol. 43, no. 1, pp. 7-23, 1996.

[19] M. Subramaniam, "Integrating Cross-Border Knowledge for Transnational New Product Development," J. Prod. Innov. Manag., vol. 23, no. 6, pp. 541-555, 2006.

[20] E. F. McDonough III, K. B. Kahn, and A. Griffin, "Managing communication in global product development teams," Eng. Manag.
IEEE Trans., vol. 46, no. 4, pp. 375-386, 1999.

[21] A. Tripathy and S. D. Eppinger, “A system architecture approach to global product development," 2007.

[22] U. De Brentani and E. J. Kleinschmidt, "Corporate culture and commitment: impact on performance of international new product development programs," $J$. Prod. Innov. Manag., vol. 21, no. 5, pp. 309-333, 2004.

[23] M. E. Sosa, S. D. Eppinger, M. Pich, D. G. McKendrick, and S. K. Stout, "Factors that influence technical communication in distributed product development: an empirical study in the telecommunications industry," Eng. Manag. IEEE Trans., vol. 49, no. 1, pp. 45-58, 2002.

[24] S. Terzi and M. Garetti, "Global Product Development in Italian companies: an empirical analysis," in International Conference on Product Lifecycle Management, 2008.

[25] C. Le Bas and C. Sierra, "'Location versus home country advantages' in R\&D activities: some further results on multinationals' locational strategies," Res. Policy, vol. 31, no. 4, pp. 589-609, 2002.

[26] M. Subramaniam, S. R. Rosenthal, and K. J. Hatten, "Global new product development processes: Preliminary findings and research propositions," J. Manag. Stud., vol. 35, no. 6, pp. 773-796, 1998.

[27] F. Caniato, L. Crippa, M. Pero, A. Sianesi, and G. Spina, "Internationalisation and outsourcing of operations and product development in the fashion industry," Prod. Plan. Control, no. ahead-of-print, pp. 1-17, 2015.

[28] M. Demirbag and K. W. Glaister, "Factors determining offshore location choice for $R \& D$ projects: A comparative study of developed and 
emerging regions," J. Manag. Stud., vol. 47, no. 8, pp. 1534-1560, 2010.

[29] S. Manning, S. Massini, and A. Y. Lewin, "A dynamic perspective on next-generation offshoring: The global sourcing of science and engineering talent," Acad. Manag. Perspect., vol. 22, no. 3, pp. 35-54, 2008.

[30] D. A. Griffith, N. Harmancioglu, and C. Droge, "Governance decisions for the offshore outsourcing of new product development in technology intensive markets," J. World Bus., vol. 44, no. 3, pp. 217-224, 2009.

[31] K. T. Ulrich and D. J. Ellison, "Beyond Make-Buy: Internalization and Integration of Design and Production," Prod. Oper. Manag., vol. 14, no. 3, pp. 315-330, 2005.

[32] N. Harmancioglu, "Portfolio of controls in outsourcing relationships for global new product development," Ind. Mark. Manag., vol. 38, no. 4, pp. 394-403, 2009.

[33] R. Smeds, P. Olivari, and M. Corso, "Continuous learning in global product development: a crosscultural comparison," Int. J.

Technol. Manag., vol. 22, no. 4, pp. 373-392, 2001.

[34] S. Kar, S. Subramanian, and D.
Saran, "Managing global R\&D operations-lessons from the trenches," Res. Manag., vol. 52, no. 2, pp. 14-21, 2009.

[35] M. Caridi, M. Pero, A. Sianesi, "Design Chain Visibility: How much information should you share with your partners during New Product Development projects?," Benchmark.: an Int. J., vol. 24, no. 5, doi: 10.1108/BIJ-04-2016-0059, 2017.

[36] K. T. Ulrich, "Eppinger, SD: Product Design and Development." New York: McGraw--Hill, 2000.

[37] R. Yin, "Case study research: Design and methods," Sage Publ. Inc, vol. 5, p. 11, 2003.

[38] M. Cachia, L. Millward. "The telephone medium and semistructured interviews: a complementary fit." Qualitative Research in Organizations and Management: An International Journal, vol. 6, no 3, pp. 265-77, 2011.

[39] R. E. Stake, The art of case study research. Sage, 1995.

[40] ISTAT, "Dati censimento industria e servizi," 2011. [Online]. Available: ISTAT http://daticensimentoindustriaeservizi.istat.it/I ndex.aspx. 


\section{Appendix 1}

\section{Questionnaire}

(Legend: $O=$ Open-ended questions, $M C=$ Multiple Choice questions)

1. Company (Name, Turnover, Number of employees, Position in the SC, Number of projects in a year, Core business) $(\mathrm{O})$

2. Interviewee (Position, Experience, Focus) (O)

3. Company products (type, markets where they are sold) $(\mathrm{O})$

4. Product development process and development unit configuration

- Phases of the product development process $(\mathrm{O})$

- Number and localization of development units of the company (MC/O)

- Are the resources working in each development unit employed by the company? (MC)

- What is the role in the product development process of each development unit? $(\mathrm{MC} / \mathrm{O})$

- Which activities are performed in each phase by each development unit? (MC/O)

- Are there external suppliers involved in the product development process? (O)

- Are the development units localized near the production facilities? (MC/O)

- Where do you sell the products developed in each development unit? (MC/O)

- Are the development units specialized in specific products, phases or markets? (MC/O)

- How do the people involved in the product development process interact and coordinate along the projects (e.g., face-to-face, IT-based tools, etc.)? How often? (MC/O)

- Why did the company decide to offshore development process activities? (MC)

- How has the number and type of development units involved in the development process changed over the last years? Why? (O)

- Have the role and activities performed by each center changed over the last years? Why? (O) 